Acta vet. scand. $1977,18,575-577$.

Brief Communication

\title{
LISTERIC SEPTICAEMIA IN SHEEP ASSOCIATED WITH TICK-BORNE FEVER (EHRLICHIOSIS OVIS)
}

Sheep is apparently fairly resistant against infections with Listeria monocytogenes ( $\mathrm{Lm})$. Grфnst $\phi l$ (unpublished) found that a high proportion of healthy sheep are carriers of $\mathrm{Lm}$. In such animals Lm may cause clinical disease when resistance is lowered. Tick-borne fever (TBF) is known to reduce the resistance against several infections ( $\emptyset$ verås 1972). This report describes listeric septicaemia associated with TBF.

\section{Case descriptions}

A gimmer of the Rygja breed was submitted to this laboratory in a moribund state after having been ill for 2 days with symptoms of dullness and depression. This gimmer had lambed 1 lamb 6 weeks earlier and had been fostering 1 lamb in addition to its own. The animals had been kept on Ixodes ricinus infected pastures for 3 weeks.

A blood sample and a sample of cerebrospinal fluid (CSF) were taken and the animal was killed in extremis. The blood sample was examined as described by Waldeland (1977). Glucose content in CSF was determined by the same method as used for blood, and total protein content was estimated as described by Meulemans (1960). Cells in the CSF-sample were counted in a Fuchs-Rosenthal counting chamber.

The main findings in the blood sample were a low serum albumin content of $2.37 \mathrm{~g} / 100 \mathrm{ml}$ and a low albumin/globulin ratio of 0.44 . The serum iron content was $66 \mu \mathrm{g} / 100 \mathrm{ml}$ and there were 7,500 neutrophile leucocytes/ $\mu$ l. Approx. $10 \%$ of them contained TBF-organisms, and a large proportion were band forms. The CSF-sample contained $2 \mathrm{mg}$ glucose $/ 100 \mathrm{ml}, 0.58 \mathrm{~g}$ protein/ $100 \mathrm{ml}$ and 330 leucocytes/ $\mu l$.

Post-mortem examination showed a swollen yellowish-brown and fragile liver with numerous white foci with a maximum diameter of $1 \mathrm{~mm}$. The adrenals and kidneys contained similar foci. The spleen was brownish-red, enlarged and tense with swollen edges.

The main histopathological findings in the liver were miliary necrotic granulomas containing detritus with cromatine clumps, small rodshaped bacteria and a mixture of polymorphonuclear 
leucocytes and lymphohistiocytic cells. Similar granulomas were present in the cortex of the adrenals and in the cortex and the medulla of the kidneys. Some kidney capillaries were occluded with bacteria. Meningitis, perivascular cuffing, microabscesses and diffuse suppurative changes were found in Medulla oblongata. Lm serotype 1 grew in pure culture from brain, heart, lung, liver, spleen and kidney.

At about the same time, another sheep of the Rygja breed, 1 year old, was found dead on a tick-infected pasture in another area. The sheep had lambed 1 lamb 6 weeks earlier and had been kept on this pasture for 3 weeks. The main gross changes were splenomegaly and a swollen liver. No histopathological examination was done. Lm serotype 4 grew in pure culture from brain, heart, lung, liver, spleen and kidney.

\section{Comments}

Listeric septicaemia has been described several times in newborn lambs, but seems to occur rarely in older sheep. A definite diagnosis of TBF can only be made when Ehrlichia ovis is found in polymorphonuclear leucocytes and monocytes by examination of blood smears. In animals which have died during the postfebrile phase of TBF, the spleen is more than 1.5 times the normal size, tense with swollen edges and brownish-red. This type of splenic enlargement in dead sheep which have been on tick-infected pastures for 2-3 weeks seems to be an indication of TBF.

A low serum albumin content has been found in experimental TBF (Grønst $\phi l$, unpublished). The low serum iron value may be an indication of stress (Grønstфl \& Øverås, unpublished).

Both ewes had been on pastures where TBF was known to occur, and both had the TBF-type of splenomegaly. They had both been kept on the same pastures the previous year, and a partial resistance should have prevented a severe TBF-infection. Nevertheless, when sheep are reexposed to Ehrlichia infected ticks every spring, a temperature rise, reappearance of TBF-bodies and leucopenia may occur, especially in younger sheep (Øverås 1962). Consequently, reduced resistance due to leucopenia (Foggie 1956) and inhibited diapedesis of neutrophils (Foster \& Cameron 1970 a) may have existed. On the other hand, latent TBF may flare up under certain conditions which reduce immunity, such as splenectomy (Foggie 1951). Reappearance of TBF-organisms during the postneutropenic neutrophilia due to Pasteu- 
rella haemolytica infection is probably associated with the same mechanism (Foster \& Cameron 1970 b).

TBF is known to increase the susceptibility of lambs to infections with various organisms, such as Staphylococcus aureus (Foggie 1956, 1959) and louping ill-virus (Gordon et al. 1962). Foggie (1951) also found pneumonia in the sequel of TBF. Later Øverås (1972) reported that TBF probably was an important predisposing factor in outbreaks of septicaemia caused by Pasteurella haemolytica and streptococci in lambs.

However, the existence of some unknown resistance-lowering factor resulting in both a relapse of TBF and an activation of a latent $\mathrm{Lm}$ infection cannot be ruled out.

Hallstein Grфnst $\varnothing l$ and Martha J. Ulvund

The State Veterinary Research Station for Small Ruminants, Høyland, Sandnes, Norway.

\section{REFERENCES}

Foggie, A.: Studies on the infectious agent of tick-borne fever in sheep. J. Path. Bact. 1951, 63, 1-15.

Foggie, A.: The effect of tick-borne fever on the resistance of lambs to Staphylococci. J. comp. Path. 1956, 66, 278-285.

Foggie, A.: Studies on the relationship of tick-bite to tick pyaemia of lambs. Ann. trop. Med. Parasit. 1959, 53, $27-34$.

Foster, W. N. M. \& A. E. Cameron: Observations on ovine strains of tick-borne fever. J. comp. Path. 1970 a, 80, $429-436$.

Foster, W. N.M.\& A. E. Cameron: Observations on the functional integrity of neutrophil leucocytes infected with tick-borne fever. J. comp. Path. 1970 b, 80, 487-491.

Gordon, W. S., A. Brownlee, D. R. Wilson \& J. MacLeod: The epizootiology of louping-ill and tick-borne fever with observations on the control of these sheep diseases. Symp., Zool. Soc., London 1962, No. $6,1-27$.

Meulemans, O.: Determination of total protein in spinal fluid with sulphosalisylic acid and trichloroacetic acid. Clin. chim. Acta 1960, 5, 757-761.

Waldeland, H.: Toxoplasmosis in sheep. Haematological, serological and parasitological studies. Acta vet. scand. 1977, 18, 248-256.

Øverås, J.: Studies on immunity to tick-borne fever in sheep in Norway. Nord. Vet.-Med. 1962, 14, 620-630.

Øverås, J.: Sjukdom hos sau på Ixodes ricinus infisert beite. (Diseases in sheep kept on Ixodes ricinus infected pastures). Norsk Vet.-T. $1972,83,561-567$.

(Received November 16, 1977).

Reprints may be requested from: Hallstein Grønst $\varnothing 1$, the State Veterinary Research Station for Small Ruminants, Postboks 248, 4301 Sandnes, Norway. 